\title{
EFFECT OF FERMENTED CACAO POD SUPPLEMENTATION ON SHEEP RUMEN MICROBIAL FERMENTATION
}

\author{
S. Wulandari ${ }^{1}$, A. Agus ${ }^{2}$, M. N. Cahyanto ${ }^{3}$ and R. Utomo ${ }^{2}$ \\ ${ }^{1}$ Department of Animal Science, Politeknik Negeri Jember, \\ Jl. Mastrip, PO BOX 164 Jember - Indonesia \\ ${ }^{2}$ Faculty of Animal Science, Gadjah Mada University, \\ Jl. Fauna, Bulaksumur, Yogyakarta - Indonesia \\ ${ }^{3}$ Faculty of Agricultural Technology, Gadjah Mada University, \\ Jl. Flora, Bulaksumur, Yogyakarta-Indonesia \\ CorrespondingE-mail:suci_ndariwulan@yahoo.com
}

Received April 25, 2014; Accepted July 28, 2014

\begin{abstract}
ABSTRAK
Tujuan penelitian ini untuk meningkatkan nilai manfaat pod kakao sebagai bahan pakan domba yang pemberiannya mencapai $50 \%$ dari total pakan. Penelitian ini terdiri dua tahap. Tahap 1 adalah fermentasi pod kakao. Rancangan acak lengkap pola faktorial 3X3 digunakan pada tahap ini. Faktor I adalah dosis inokulum mikrobia $0 \%, 0,05 \%$ dan $0,1 \%$. Faktor II adalah lama pemeraman 0,3 , dan 6 hari. Hasil penelitian menunjukkan perlakuan lama fermentasi enam hari dengan dosis inokulum mikrobia $0,05 \%$ dapat menurunkan NDF, ADF dan theobromin pod kakao. Dosis inokulum dan waktu fermentasi terbaik dari percobaan tahap 1 diaplikasikan pada penelitian tahap 2. Penelitian tahap 2 adalah percobaan fermentasi mikrobia rumen. Penelitian ini menggunakan rancangan bujur sangkar latin 3X3. Pada periode I domba diberi pakan perlakuan CF0 (complete feed tanpa fermentasi), periode II: CF1 (complete feed mengandung pod kakao fermentasi), dan periode III: CF2 (complete feed fermentasi berbasis pod kakao). Hasil penelitian menunjukkan nilai $\mathrm{pH}$ cairan rumen domba perlakuan $\mathrm{CF} 0, \mathrm{CF} 1$ dan CF2 masih dalam kisaran pH normal, dan tidak berpengaruh terhadap asam lemak volatil (VFA) dan amonia. Kesimpulan penelitian ini adalah pemberian complete feed yang mengandung pod kakao sampai $50 \%$ pada domba, baik difermentasi maupun tanpa fermentasi tidak mempengaruhi proses fermentasi mikrobia rumen.
\end{abstract}

Kata Kunci: pod kakao, fermentasi, complete feed, fermentasi mikrobia rumen, domba

\begin{abstract}
The objective of this research was to improve beneficial value of cacao pod as sheep feed ingredients comprising up to $50 \%$ total feed. This research was conducted in two stages. Stage 1 was cacao pod fermentation. Completely randomized design with $3 \times 3$ factorial patterns was used in this stage, in which factor I was microbial inoculum dosage of $0 \%, 0.05 \%$ and $0.1 \%$ and factor II was incubation period of 0,3 and 6 days. Result demonstrated that six-day fermentation with $0.05 \%$ microbial inoculum could lower cacao NDF, ADF and theobromine. The optimum inoculum dosage and fermentation time from stage 1 was applied to stage 2 . Stage 2 was rumen microbial fermentation test. This research administrated $3 \times 3$ of latin square design. In period I sheep were fed with CF0 (nonfermented complete feed), in period II sheep were given CF 1 (complete feed containing fermented cacao pod) and in period III sheep were given CF2 (fermented complete feed based cacao pod). Result demonstrated that $\mathrm{pH}$ value of sheep microbial liquid in treatment of CF0, CF1 and CF2 was in normal $\mathrm{pH}$ range and did not affect volatile fatty acids (VFA) and ammonia. In conclusion, supplementing up to
\end{abstract}


$50 \%$ of feed with complete feed containing fermented or non-fermented cacao pod did not affect the process of rumen microbial fermentation.

Keywords: cacao pod, fermentation, complete feed, rumen microbial fermentation, sheep

\section{INTRODUCTION}

Indonesia produces considerable amount of cacao. In 2012 cacao production reached 740,513 thousand tons with $3.8 \%$ average annual growth (Pusat Data dan Sistem Informasi Pertanian, 2013). Cacao pod is the biggest part of cacao fruit comprising 75\% (Syamsu and Ishak, 2002). Cocoa pod is one of the major waste of agroindustry is the potential to be used as animal feed ingredients which are cheap. Nutrient content of the cocoa pod consists of $8 \%$ crude protein $(\mathrm{CP})$, $40 \%$ crude fiber (CF), $50.8 \%$ total digestible nutrients (TDN), and its use by ruminants $30-40 \%$ (BPPT Sulawesi Selatan, 2008).

Utilizing cacao pod as feed is limited by anti-nutrition substance or alkaloid named theobromine (3,7-dimethylxantine). Theobromine in cacao pod can reduce feed consumption and overconsumption of theobromine may induce health disorder in sheep. Directly fed cacao pod to sheep will lower body weight because high lignocellulose causes low cacao pod digestibility. Cellulose and hemicellulose content in cacao pod are $35 \%$ and $11 \%$, respectively (Alemawor et al., 2009). The relatively safe, applicable and environmental-friendly way to improve cacao pod quality is through biological treatment namely microbial inoculum fermentation.

The recently widespread additive fermentation for waste-based complete feed is microbial inoculum. Vast microbial diversity in Indonesia provides high probability of finding potential isolate to develop as inoculum in fermentation process. The objective of this research was to study microbial inoculum utilization in form of microbial composites such as cellulosic microbe, lactic acid and amylolytic to cope with theobromine anti-nutrition and cacao pod crude fiber and to examine the effect of administering fermented complete feed (cacao pod as raw material) on sheep rumen microbes.

\section{MATERIALS AND METHODS}

\section{Cacao Pod Fermentation.}

Cacao pod was obtained from plantation in

Patuk, Gunungkidul Regency, Yogyakarta. Microbial inoculum of Saus Burger Pakan
$\left(\mathrm{SBP}^{\circledR}\right)$ was produced by CV. Agro Indo Utama, Yogya. Molasses used was $2 \%$ of feed.

Eight hundreds $g$ of sterilized ground cacao pod was thoroughly mixed with microbial inoculum (activated in solution molasses) according to treatment dosage, then it was added with sterilized aquadest to make up $40 \%$ water content. Dosage molasses was $2 \%$ of total cacao powder. The mixture were placed in mini silo (1 $\mathrm{kg}$ of sterile bottle), compressed to achieve the anaerobic conditions, measured, tightly sealed then was fermented.

Experimental design used was $3 \times 3$ Factorial completely randomized design. Factor I was inoculum microbial dosage, namely $0 \mathrm{~mL} / 100 \mathrm{~g}$; $0.05 \%=0.05 \mathrm{~mL} / 100 \mathrm{~g}$ and $0.1=0.1 \mathrm{~mL} / 100 \mathrm{~g}$ as feed. Factor II was fermentation period, that was 0,3 , and 6 days. Each treatment comprised three replicates. Data were tested by using analysis of variance, then it was followed by Duncan test for different result (Astuti, 2007). The observed parameters were fiber composition change (neutral detergent fiber/NDF, acid detergent fiber /ADF) and theobromine degradation. The optimum inoculum dosage and fermentation period at this stage was applied to cacao pod as raw material of complete feed and to observe the effect on rumen microbial fermentation.

\section{Rumen Microbial Fermentation Test}

Three rumen fistulated local male sheep (averaged about $33 \mathrm{~kg}$ ) were used in the study. The ingredient of complete feed were elephant grass and cacao pod as fiber source. The other ingredients were rice bran, pollard, soybean meal and microbial inoculum $\left(\mathrm{SBP}^{\circledR}\right)$.

The experiment was conducted in $3 \times 3$ latin square design with three treatment feeds and three fermentation periods as replicates. In Period I sheep were given CF0 feed treatment or 50\% nonfermented complete feed consisted of nonfermented cacao pod $+40 \%$ of concentrate $+10 \%$ of elepahant grass; in Period II sheep were given CF1 or fermented cacao pod-contained complete feed consisted of $50 \%$ of fermented cacao pod + $40 \%$ of concentrate $+10 \%$ of elephant grass, and in Period III sheep were given CF2 or cacao podbased silage complete feed as a the fermentation 
result of $50 \%$ of cacao pod $+40 \%$ of concentrate $+10 \%$ of elephant grass.

Feed was given for 10 days on each period, including adaptation period. Water was provided daily. The $\mathrm{pH}$ was determined after extracting rumen contents. The sample was filtered by using four-layer lint to measure rumen ammonia $\left(\mathrm{NH}_{3}\right)$ and volatile fatty acids (VFA) concentration. Each sample was placed in $25 \mathrm{ml}$ plastic bottle and stored in $-5^{\circ} \mathrm{C}$ freezer until $\mathrm{NH}_{3}$ and VFA were analyzed. The obtained data were subject to analysis of variance and different result was followed by Duncan test (Astuti, 2007). The observed parameters comprised acidity $(\mathrm{pH})$ (AOAC, 2005), carbohydrate metabolism: total VFA concentration (Doreau et al., 1993), protein metabolism: $\mathrm{N}^{-\mathrm{NH}_{3}}$ level (Chaney and Marbach, 1962).

\section{RESULTS AND DISCUSSION}

\section{Conversion of Cacao Pod Fiber Composition during Fermentation}

Cell wall components can be determined for instance by calculating NDF content (Jancik et al., 2008) in which the main components of NDF are cellulose, hemicellulose and lignin (Van Soest et al., 1991). The result demonstrated that treatment dosage and fermentation period significantly affected NDF content, and interaction was observed (Table 1). The lowest fiber content was in $0.5 \%$ microbial inoculum dosage with 6-day fermentation, shown by low NDF value of $54.9 \%$. the highest NDF value or $71.2 \%$ was at $0 \%$ inoculum dosage with 0 -day fermentation

It showed that cell wall restructuring microbial activity was still in effect after three days, while double dosage addition $(0.1 \%$ at $40 \%$ KA) could decrease NDF because double dosage of microbial inoculum had failed to significantly increase the number of bacteria. Result of Wulandari et al. (2014) demonstrated that the total bacteria in fermented cacao pod with additional microbial inoculum was $7.6 \times 10^{4} \mathrm{cfu} / \mathrm{g}$ became $5.8 \times 10^{4} \mathrm{cfu} / \mathrm{g}$ for $0.05 \%$ and $0.1 \%$ dosage, respectively. Total bacteria consisted of cellulosic bacteria and lactic acid bacteria (LAB). Total bacteria needed for minimum anaerobic fermentation was $1.6 \times 10^{5}$, consisted of $1.16 \times 10^{5}$ cfu/g cellulosic bacteria (McDonald et al., 1991) and 1.0x105 cfu/g LAB (Kung, 2001). The average NDF content in cacao pod was more than $35 \%$ and therefore belongs to the first class feed (Hartadi et al., 2005).

ADF main components are cellulose and lignin. Cellulosic bacteria in microbial inoculum added in fermented cacao pod could degrade cacao pod cell wall as shown in Table 2. The result of $\mathrm{ADF}$ analysis demonstrated that $0.05 \%$ of microbial inoculum could lower cacao pod ADF from 42.4 to $39.1 \%$ DM (dry matter) due to the cellulase enzyme produced by cellulosic bacteria developing during fermentation. According to Lin et al. (2012), cellulase enzyme is a complex enzyme that gradually cuts intermolecular at $\beta$-1,4-glycosidic bond, cutting cellulose chain into cellobiose units, then cutting cellobiose and oligosaccharide, producing glucose.

\section{Theobromine Degradation during Cacao Pod Fermentation}

Result showed that fermentation period

Table 1. NDF Content in Fermented Cacao Pod (\%DM)

\begin{tabular}{|c|c|c|c|c|c|}
\hline \multirow{2}{*}{$\begin{array}{c}\text { Fermentation Period } \\
\text { (day) }\end{array}$} & \multicolumn{3}{|c|}{ Microbial Inoculum Dosage (\%) } & \multirow{2}{*}{ Mean } & \multirow{2}{*}{ SEM } \\
\hline & 0 & 0.05 & 0.1 & & \\
\hline 0 & $71.2^{\mathrm{a}}$ & $58.1^{\mathrm{bc}}$ & $60.1^{\mathrm{bc}}$ & $63.1^{\mathrm{a}}$ & 2.28 \\
\hline 3 & $70.3^{\mathrm{a}}$ & $55.4^{\mathrm{bc}}$ & $60.7^{\mathrm{bc}}$ & $62.1^{\mathrm{a}}$ & 2.35 \\
\hline 6 & $56.3^{\mathrm{b}}$ & $54.9^{\mathrm{c}}$ & $61.3^{\mathrm{b}}$ & $57.5^{\mathrm{b}}$ & 1.31 \\
\hline Mean & $65.9^{\mathrm{a}}$ & $56.2^{\mathrm{c}}$ & $60.7^{\mathrm{b}}$ & & \\
\hline SEM & 2.59 & 1.24 & 0.65 & & \\
\hline
\end{tabular}

${ }^{a b c}$ Different superscript in the same column and line show significantly difference $(\mathrm{P} \leq 0.05)$. 
Table 2. ADF Content in Fermented Cacao Pod (\%DM)

\begin{tabular}{cccccc}
\hline \multirow{2}{*}{$\begin{array}{c}\text { Fermentation Period } \\
\text { (day) }\end{array}$} & \multicolumn{2}{c}{ Microbial Inoculum Dosage $(\%)$} & Mean & SEM \\
\cline { 2 - 4 } & 0 & 0.05 & 0.1 & & \\
\hline 3 & $43.3^{\mathrm{ab}}$ & $38.8^{\mathrm{bc}}$ & $40.0^{\mathrm{abc}}$ & 40.7 & 0.88 \\
& $43.9^{\mathrm{a}}$ & $40.2^{\mathrm{abc}}$ & $38.6^{\mathrm{bc}}$ & 40.9 & 0.99 \\
Mean & $40.1^{\mathrm{abc}}$ & $38.2^{\mathrm{c}}$ & $43.7^{\mathrm{a}}$ & 40.7 & 1.22 \\
SEM & $42.4^{\mathrm{a}}$ & $39.1^{\mathrm{b}}$ & $40.8^{\mathrm{ab}}$ & 40.7 & \\
\hline
\end{tabular}

${ }^{a b c}$ Different superscript in the same column shows significantly difference $(\mathrm{P} \leq 0.05)$.

Table 3. Theobromin Content in Fermented Cacao Pod (ppm)

\begin{tabular}{|c|c|c|c|c|c|}
\hline \multirow{2}{*}{$\begin{array}{c}\text { Fermentation Period } \\
\text { (day) }\end{array}$} & \multicolumn{3}{|c|}{ Microbial Inoculum Dosage (\%) } & \multirow{2}{*}{ Mean } & \multirow{2}{*}{ SEM } \\
\hline & 0 & 0.05 & 0.1 & & \\
\hline 0 & 116.5 & 127.0 & 128.1 & $123.9^{\mathrm{a}}$ & 4.07 \\
\hline 3 & 116.5 & 108.9 & 122.8 & $116.1^{\mathrm{a}}$ & 3.59 \\
\hline 6 & 108.2 & 101.8 & 98.4 & $102.8^{\mathrm{b}}$ & 3.89 \\
\hline Mean & 113.8 & 112.6 & 116.4 & & \\
\hline SEM & 4.55 & 5.70 & 5.94 & & \\
\hline
\end{tabular}

${ }^{\mathrm{ab}}$ Different superscript in the same column showssignificantly difference $(\mathrm{P} \leq 0.05)$.

significantly affected theobromine content in fermented cacao pod as presented in Table 3. Sixday fermentation decreased $17.02 \%$ theobromine from $123.88 \mathrm{ppm}$ at early fermentation to 102.79 ppm after six days. Bacteria needed carbohydrate resources or simple sugar probably resulted from cacao pod degradation to stimulate theobromine degradation. Accordingly, optimum theobromine degradation required proper period. Gokulakrishnan et al. (2006) reported that sucrose in media will stimulate the activity of caffeine and theobromine degrading enzyme from Pseudomonas sp. bacteria. Lactose enables disaccharide, comprising galactose and glucose, to degrade caffeine up to more than $90 \%$.

Temperature raise during fermentation was likely to affect theobromine degradation causing theobromine content decrease. It was similar to theobromin degradation due to boiling or drying heat. Sukha (2003) stated that cacao pod is harmless feed, in which theobromine is removed by 1.5 of boiling or heating. From the high amount of theobromine degradation, it was observed that to lower amount of theobromine in fermented cacao pod containing $40 \%$ water was 6-days of fermentation.

Result of period I demonstrated that cellulosic bacteria from microbial inoculum growing in fermented cacao pod was capable of degrading fiber and lowering theobromine. The optimum and economical dosage of microbial inoculum was $0.05 \%$ with 6 -days of fermentation, then applied to cacao pod as complete feed raw material in the next analysis stage.

\section{Rumen Microbial Fermentation Acidity (pH) of rumen liquid}

Result of $\mathrm{pH}$ measurement is presented in Table 4. Composite result of rumen liquid extraction for 24 hours showed that the three 
Table 4. $\mathrm{pH}$ Value and Total VFA Concentration, $\mathrm{NH}_{3}$ (Amonia), Sheep Rumen Liquid Fed on Ration with 50\% Cacao Pod

\begin{tabular}{lrrr}
\hline \multirow{2}{*}{ 24 Hour Composite } & \multicolumn{3}{c}{ Treatment } \\
\cline { 2 - 4 } & \multicolumn{1}{c}{ CF0 } & \multicolumn{1}{c}{ CF1 } & \multicolumn{1}{c}{ CF2 } \\
\hline $\mathrm{pH}$ & $6.4^{\mathrm{ab}} \pm 0.03$ & $6.3^{\mathrm{b}} \pm 0.06$ & $6.5^{\mathrm{a}} \pm 0.06$ \\
$\mathrm{VFA}^{\mathrm{ns}}$ & $128.3 \pm 78.31$ & $127.4 \pm 6.07$ & $129.7 \pm 29.90$ \\
$\mathrm{NH}_{3} /$ amonia $^{\mathrm{ns}}$ & $6.4 \pm 3.92$ & $6.4 \pm 0.30$ & $6.5 \pm 1.49$ \\
\hline
\end{tabular}

${ }^{a b c}$ Different superscript in the same column and line show significantly difference $(\mathrm{P} \leq 0.05)$.

ns non-significant

treatments (CF0, CF1 and CF2) demonstrated significantly different in $\mathrm{pH}$. The $\mathrm{CF} 1$ had the lowest $\mathrm{pH}$ value because the administered cacao pod was priorly fermented, therefore more cellulose degradation occurred as shown by the declining NDF and ADF content in cacao pod (Table 1 and Table 2) and being more fermentable in rumen into organic acids like VFA and lactic acid. Cellulase enzyme of microbial rumen would degrade cellulose into glucose. LAB would fermented glucose into lactic acid and affected $\mathrm{pH}$ decline (Wulandari et al., 2014).

The average $\mathrm{pH}$ value of 24 hour rumen liquid composite in CF0, CF1 and CF2 was $6.4 \pm$ $0.03 ; 6.3 \pm 0.06$ and $6.5 \pm 0.06$, respectively, or within normal range for sheep $\mathrm{pH}$ value. Jasmin et al. (2011) stated that normal sheep rumen $\mathrm{pH}$ ranges from 6.4 to 6.8 , therefore, $\mathrm{pH}$ less than 5.5 or more than 7 is considered as abnormal $\mathrm{pH}$. It proved that complete feed containing 50\% DM fermented or non-fermented cacao pod supplementation can be administered to sheep without interrupting rumen fermentation.

Observation result on rumen liquid $\mathrm{pH}$ kinetics is presented in Figure 1 showing that rumen $\mathrm{pH}$ decrease after feed was given to all treatments. The $\mathrm{pH}$ decrease in $\mathrm{CF} 1$ was significant particularly within 2 to 3 hours post feeding (10 and $11 \mathrm{a}$ a.m.), that was $6.0 \pm 0.08$ and $5.8 \pm 0.26$, respectively. Rumen liquid was acid because during 1-3 hour post feeding the CF1 containing the fermented cacao pod was digested more quickly and produced organic acids like VFA. The $\mathrm{pH}$ less than 5.5 would be acidotic without clinical symptoms (Jasmine et al., 2011). The $\mathrm{pH}$ kinetics of rumen liquid in CF0 and CF2 was in normal bacterial range (6-7); accordingly,

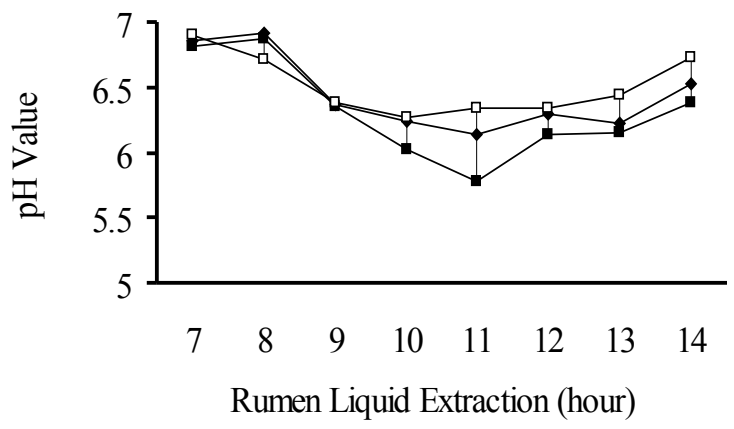

Figure 1. The pH Kinetics of Sheep Rumen Liquid Fed on Ration with $50 \%$ Cacao Pod. The symbols represent $\mathrm{CF} 0=$ non-fermented complete feed $(\diamond), \quad \mathrm{CF} 1=$ complete feed containing fermented cacao pod $(\boldsymbol{\square})$, and $\mathrm{CF} 2=$ fermented complete feed $(\square)$.

it did not interrupt rumen fermentation process. Conducive rumen environment would support the maximum microbial growth (Uhi et al., 2006).

\section{Carbohydrate Metabolism: Total VFA}

Effect of non-fermented (CF0) or fermented (CF1 and CF2) cacao pod-based complete feed on rumen liquid VFA is presented on Table 4. Result demonstrated that utilizing of cacao pod basedcomplete feed in CF0, CF1 and CF2 showed non significantly different result towards VFA concentration of sheep rumen liquid. The average VFA concentration (Mmol) in all treatments from rumen liquid composite extracting for 24 hours were $128.3 \pm 78.31$ (CF0), $127.4 \pm 6.07$ (CF1) and $129.7 \pm 29.90$ (CF2), showing optimal VFA 


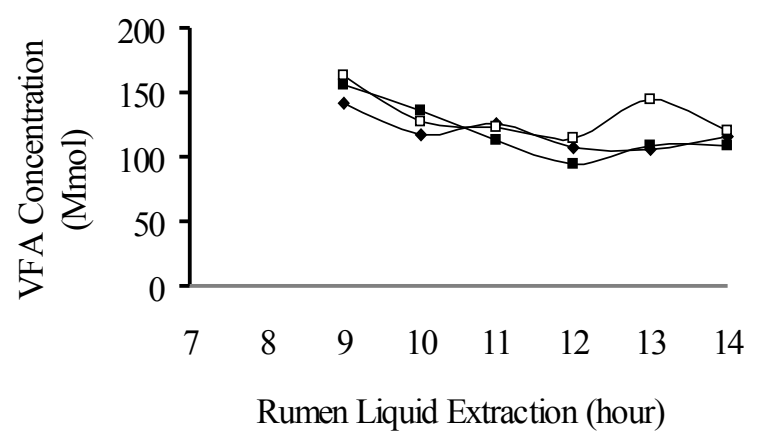

Figure 2. VFA Kinetics Concentration of Sheep Rumen Liquid Fed on Ration with $50 \%$ Cacao Pod. The symbols represent $\mathrm{CF} 0=$ non-fermented complete feed $(\bullet), \quad \mathrm{CF} 1=$ complete feed containing fermented cacao pod $(\boldsymbol{\square})$, and $\mathrm{CF} 2=$ fermented complete feed ( $\square$ ).

for microbial rumen activity. Sufficient VFA concentration for rumen microbial growth is 80 180Mmol (Fathul and Wajizah, 2009).

Kinetic of VFA concentration is presented in Figure 2. It showed a fast increase after feeding due to fast fermentation rate as a result of high soluble carbohydrate in feed either in form of additional molasses in complete feed (in CF0, $\mathrm{CF} 1$ and CF2) or product of fermented anaerobe restructuring with microbial inoculum addition (CF1 and CF2). However, CF2 (fermented complete feed with additional microbial inoculum) tended to produce the highest VFA. It showed that CF2 had the highest fiber digestibility due to silage process with additional microbial inoculum containing cellulosic bacteria. The final result of carbohydrate fermentation among which was VFA (McDonald et al., 2002).

VFA rumen liquid decreased in kinetics concentration was due to cell-wall absorption. Saqifah et al. (2010) reported that a part of VFA was produced in rumen diminished from ruminal wall absorption.

\section{Protein Metabolism: $\mathrm{NH}_{3}$}

Ammonia in rumen liquid was the sign of protein degradation entering the rumen and protein synthesis process by rumen microbes, half of which would be degraded by protolithic enzyme of rumen microbes. Concentration of rumen ammonia extracted periodically within 24 hours and rumen liquid composite are presented in Table 4.

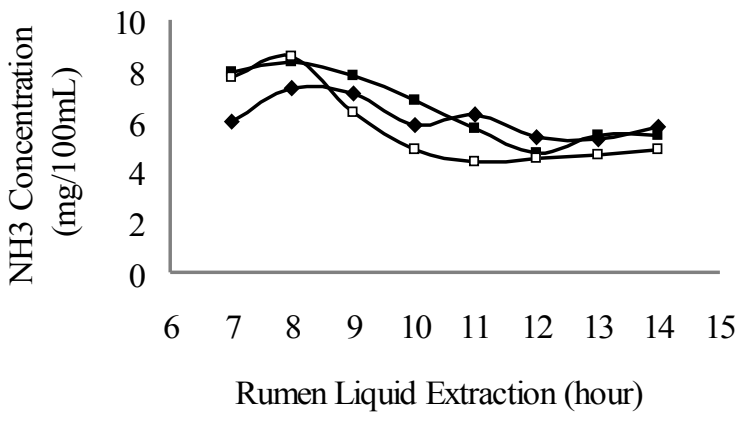

Figure 3. Amonia $\left(\mathrm{NH}_{3}\right)$ Kinetics Concentration of Sheep Rumen Liquid Fed on Ration with 50\% Cacao Pod. The symbols represent $\mathrm{CF} 0=$ nonfermented complete feed $(\diamond), \mathrm{CF} 1=$ complete feed containing fermented cacao pod (ם), and $\mathrm{CF} 2=$ fermented complete feed $(\square)$.

Result showed no significant difference between CF0, CF1 and CF2, in which ammonia concentration from composite were $6.4 \pm 3.92$; $6.4 \pm 0.30$ and $6.5 \pm 1.49 \mathrm{mg} / 100 \mathrm{~mL}$, respectively. It proved that ammonia concentration of rumen liquid in the treatments of either fermented or non-fermented cacao podbased complete feed was still within normal range for rumen microbial growth. According to Satter and Slyter (1973), rumen microbial growth requires $4-8 \mathrm{mg} / 100 \mathrm{~mL}$ ammonia concentration. Ammonia concentration reflected protein fermentability level in rumen (Fathul and Wajizah, 2009).

Figure 3 shows kinetics change in ammonia concentration $\left(\mathrm{NH}_{3}\right)$, in which the highest ammonia occurred one hour post-feeding in CF0, CF1 and CF2, that were $7.3 \pm 3.52 ; 8.4 \pm 1.88$; and $8.5 \pm 3.60 \mathrm{mg} / 100 \mathrm{~mL}$, respectively. This was due to protein feed degradation by protease rumen microbes where protein feed was degraded into amino acid and ammonia, then ammonia product would be reused by rumen microbes for its growth. According to Arora (1995), utilizing ammonia by microbial rumen was ever increasing up to $8.5 \mathrm{mg} / 100 \mathrm{~mL}$.

Result of research stage II showed that cacao pod supplementation (as complete feed) up to $50 \%$ feed either fermented or non-fermented was utilizable for sheep without disrupting rumen fermentation process. VFA and ammonia concentration were in normal range for rumen microbial growth. 


\section{CONCLUSION}

Saus Burger Pakan (SBP) microbial inoculum was viable fermenter to improve digestibility and reduction of cacao pod theobromine with optimum dosage of $0.05 \%$ within six day incubation with $40 \%$ water content. Feeding complete feed containing $50 \%$ cacao pod for sheep did not affect the rumen microbes' fermentation process. VFA and ammonia concentration was within normal range for microbial growth.

\section{REFERENCES}

AOAC. 2005. Official Methods of Analysis of AOAC International. AOAC International. Maryland.

Alemawor, F., V. P. Dzogbefia, E. O. K Oddoye and J. H. Oldham. 2009. Effect of Pleurotus ostreatus fermentation on cocoa pod husk composition: Influence of fermentation period and $\mathrm{Mn}^{2+}$ supplementation on the fermentation process. Afric. J. Biotechnol. 8(9):1950-1958.

Arora, S. P. 1995. Pencernaan Mikroba pada Ruminansia. (Translated by R. Murwani and Srigandono). Gadjah Mada University Press. Yogyakarta.

Astuti, M. 2007. Pengantar Ilmu Statistik untuk Peternakan dan Kesehatan Hewan. Cetakan Pertama. Binasti, Bogor.

BPPT (Balai Pengkajian Teknologi Pertanian) Sulawesi Selatan. 2008. Pemanfaatan Limbah Kulit Buah Kakao sebagai Pakan Kambing. Kementerian Pertanian Republik Indonesia.

Chaney, A. L. and E. P. Marbach. 1962. Modified reagents for determination of urea and amonia. Clinical Chemestry. 8(2):130-132.

Doreau, M., B. Salem, and R. R. Krezminski. 1993. Effect of rapeseed oil supply on in vitro ruminal digestion in cows: comparison of hay and maize silage diets. J. Anim. Feed Sci. Technol. 44:181-189.

Fathul, F. and S. Wajizah. 2009. Penambahan mikromineral $\mathrm{Mn}$ dan $\mathrm{Cu}$ dalam ransum terhadap aktivitas biofermentasi rumen domba secara in vitro. Jurnal Ilmu Ternak dan Veteriner . 15(1):9-15.

Gokulakrishnan, S., K. Chandraraj and S. N. Gummadi. 2006. A preliminary study of caffeine degradation by Pseudomonas sp. GSC 1182. Int. Food Microbiol.
113(3):346-350.

Hartadi, H., S. Reksohadiprodjo, dan A.D. Tillman. 2005. .Tabel Komposisi Pakan untuk Indonesia. Cetakan Ke-5. Gadjah Mada University Press, Yogyakarta.

Jancik, F., P. Homolka, B. Cermak, and F. Lad. 2008. Determination of indigestible neutral detergent fibre contents of grasses and its prediction from chemical composition. J. Anim. Sci. 53(3):128-135.

Jasmin, B. H., Ray. C. B., R. B. Modesto and P.S. Thomas. 2011. Perioperative ruminal $\mathrm{pH}$ changes in domestic sheep (Ovis aries) housed in a biomedical research setting. $\mathrm{J}$ Am. Assoc. Lab. Anim. Sci. 50(1): 27-32.

Kung, L. 2001. Silage Fermentation and Additives. In: Direct-fed Microbial, Enzyme and Forage Additive Compendium. Miller Publishing Co., Minnetonka.

Lin, L., X. Kan, H. Yan and D. Wang. 2012. Characterization of extracellular cellulosedegrading enzymes from Bacillus thuringiensis strains. Electron. J. Biotechnol. 15(3):1-7.

McDonald, P., A. R. Henderson and S. J. Heron. 1991. The Biochemistry of Silage. Chalcombe Publications, 13 Highwoods Drive, Marlow Bottom

McDonald, P., R. A. Edward, and J. F. O. Greenhalgh. 2002. Animal Nutrition. Longman Scientific and Technical. John Willey, Sons. Inc, New York. 445-484.

Pusat Data dan Sistem Informasi Pertanian. 2013. Statistik Pertanian 2013. Kementerian Pertanian Republik Indonesia.

Saqifah, N., E. Purbowati, dan E. Rianto. 2010. Pengaruh ampas teh dalam pakan konsentrat terhadap konsentrasi VFA dan $\mathrm{NH}_{3}$ cairan rumen untuk mendukung pertumbuhan sapi peranakan Ongole. Prosiding Seminar Nasional Peternakan dan Veteriner. Balai Penelitian Ternak. Bogor. 205-2010.

Satter, L. D. and L. L. Slyter. 1973. Effect of ammonia concentration on rumen microbial protein production in vitro. Br. J. Nutr. 32:199-208.

Sukha, D. A. 2003. Potential value added products from Trinidad and Tobago cocoa. Proc.of Sem./Exhibition on The Revitalization on The Trinidad and Tobago Cocoa IndustryTargets, Problems and Options. The Association of Professional Agricultural Scients of Trinidad and Tobago (APASTT). 
Faculty of Science and Agriculture. The University of The West Indies. St. Augustine. $20^{\text {th }}$ September 2003. p.69-73.

Syamsu, J.A. and A.B. L. Ishak. 2002. Fermentasi pod cacao sebagai sumber pakan ternak ruminansia. Prosiding Seminar Nasional Inovasi Teknologi Tepat Guna Berorientasi Agribisnis untuk Pemberdayaan Masyarakat dalam Pembangunan Pertanian Wilayah, Puslitbang Sosial Ekonomi Pertanian Deptan. Kendari 6-7 August 2002. P. 77-81.

Uhi, H. T., A. Parakkasi and B. Haryanto. 2006. Pengaruh suplemen katalitik terhadap karakteristik dan populasi mikroba rumen domba. Media Peternakan. 29(1):20-26

Van Soest, P.J., J.B. Robertson and B.A. Lewis. 1991. Methods for dietary fiber, neutral detergent fiber, and nonstarch polysaccharides in relation to animal nutrition. J. Dairy Sci. (74):3583-3597.

Wulandari, S., A. Agus, M. Soejono and M. N. Cahyanto. 2014. Nilai cerna dan biodegradasi theobromin pod kakao dengan perlakuan fermentasi menggunakan inokulum multi mikrobia. Agritech. 34(2):160-169. 